\title{
Anti-tumor pharmacological evaluation of extracts from stellera chamaejasme $L$ based on hollow fiber assay
}

\author{
Xiaoni Liu', Qing Yang ${ }^{2}$, Ganlin Zhang ${ }^{2}$, Yujie Li ${ }^{2}$, Ying Chen², Xiaogang Weng², Yajie Wang ${ }^{2}$, Yiwei Wang ${ }^{2}$
} and Xiaoxin Zhu ${ }^{2 *}$

\begin{abstract}
Background: Stellera chamaejasme L, a traditional Chinese herb, has long been used for treatment of various tumors in the Chinese population. In our previous study, we paid an attention to the cytotoxic and proapoptotic effects of Stellera chamaejasme $L$ extracts (ESC, ESC-1 and ESC-2, the latter two were isolated from ESC) on 4 various tumor cells (NCl-H157, NCl-H460, BEL-7402 and SK-HEP-1) in vitro. ESCs showed significantly inhibitory effects on the 4 tumor cells. ESC-2 had the strongest inhibitory effect and the broadest sensitive cell spectrum. ESC-2 and ESC acted in a similar way against tumor cells, which suggested anti-tumor active fraction of ESC might exist in ESC-2. Here, we further observe the inhibitory and proapoptotic effects of Stellera chamaejasme $L$ extracts in vivo.

Methods: In this study, we used hollow fiber tumor model to evaluate the inhibitory and proapoptotic effects of Stellera chamaejasme $L$ extracts. Apoptotic rates of the cancer cells retrieved from the hollow fibers were measured with flow cytometric analysis, caspase 3, 8, 9 enzyme activities were detected by colorimetric assay, Fas, Fas-L, TNF-R1 and TNF-a expression were determined with elisa assay and radioimmunoassay respectively.

Results: The results showed that ESC, ESC-2 all had inhibitory effects on 4 tumor cells. According to the effect strength, dose and antitumor spectrum, the order of antitumor effects of ESCs was: ESC-2 > ESC > ESC-1. NCl-H460 cells were the most sensitive to ESCS. ESC, ESC-2 increased greatly the apoptotic rate and caspase 3, 8 enzyme activities in $\mathrm{NCl}-\mathrm{H} 460$. ESCs had no significant effects on expression of Fas, Fas-L protein, but TNF-a/TNFR1 protein expression in NCl-H460 cells changed significantly after ESC and ESC-2 treatment.
\end{abstract}

Conclusion: ESC-2 had the similar antitumor effect to that of ESC in vivo and further confirmed that ESC-2 may be the main antitumor active fraction of ESC, which was consistent with our previous results in vitro.

Keywords: Stellera chamaejasme L, Hollow fiber assay, Apoptosis, Caspase activity, Fas, TNF-a

\section{Background}

In vitro cytotoxicity experiment is the first step for screening or discovery of anti-tumor drug. It has the advantages of reducing substantially the amount of test drugs, determining the tumor specificity of the test drugs, simple experiment, low cost, etc. So, it is also easily adopted as the approach for pharmacological researchers to tracing active ingredients or fractions of most anti-tumor nature

\footnotetext{
* Correspondence: zhuxx59@163.com

${ }^{2}$ Institute of Chinese Materia Medica, China Academy of Chinese Medical Sciences, No 16 Nan Xiao Jie, Dong Zhi Men Nei, Dong Cheng Qu, Beijing 100700, China

Full list of author information is available at the end of the article
}

products, especially medicinal herbs. However, each herb in body is subjected to process of transport and metabolism, which makes the experimental results in vitro and in vivo always inconsistent. In particular, distinctive action characteristics of traditional Chinese herbs based on its integrity and interaction with the body determine the importance and necessity of investigating the efficacy in vivo. Therefore animal experiments must be conducted to verify the validity of the test samples, which is the critical step for active ingredients or fractions screening of traditional Chinese herbs. Xenograft is once the main the model for anti-tumor drug screening. But this kind of model is difficult to be as the large-scale screening method because it

\section{Biomed Central}


demands a large number of experimental animals and the test samples, consuming large amounts of time and manpower. Hollow fiber assay (HFA) is a high-throughput in vivo screening system built up by US National Cancer Institute (NCI) in 1995 [1] and has become one of the conventional anticancer drug screening method in NCI, which make it become reality to screen antitumor agents in large scale [2]. Because HFA can provide the real in vivo environment,in accordance with the action characteristics of natural products involving traditional Chinese herbs, HFA has potential broad application prospects in antitumor research field of traditional Chinese herbs and other natural products [3]. Moreover, a large number of research results showed that HFA was also an effective method to quickly research pharmacodynamics (e.g., Pervilleines B and C [4], Paclitaxel and Pacliex [5], C1311 and SJG-13 [6], ASI-145 [7], YSL [8], TAS-102 [9]) and mechanism (e.g., PCNA and Rb [10], p16 [11], NF-kappa B [12]) of antitumor drugs.

In our previous study, we paid attention to the cytotoxic and proapoptotic effects of Stellera chamaejasme $L$ (a traditional Chinese herb) extracts (ESC, ESC-1 and ESC-2 were obtained with special techniques described as Materials and Methods below) on 4 various tumor cells (two lung cancer cell lines: NCI-H157 and NCIH460; two liver cancer cell lines: BEL-7402 and SKHEP-1) in vitro. The results showed ESC, ESC-1, ESC-2 all had inhibitory effects on the 4 tumor cells. On 72 hours, inhibition rates of 100, $200 \mu \mathrm{g} / \mathrm{mL}$ ESCs on the 4 tumor cells were $64.82 \%-92.27 \%$. ESC-2 had the strongest inhibitory effect and the broadest sensitive cell spectrum. $\mathrm{GI}_{50}$, TGI and $\mathrm{LC}_{50}$ of ESC-2 were similar to those of ESC. These results suggested that antitumor effects of ESC-2 and ESC acted in a similar way, anti-tumor active fractions of ESC may exist in ESC-2 [13]. ESC and ESC-2 could induce the apoptosis by activating the key proteins of tumor apoptosis pathway in NCI-H460 cells $[14,15]$. Here, we further observe the inhibitory and proapoptotic effects of Stellera chamaejasme $L$ extracts using HFA to confirm the in vitro effects of ESCs.

\section{Methods}

\section{Preparation of Stellera chamaejasme $L$ extracts}

Process of ESC (extract of Stellera chamaejasme L) was given in another paper [14], ESC was mixed with reversed silica, filtered through a C18 column and eluted with 70\%, 100\% methanol respectively and the final samples were ESC-1 and ESC-2. Part components of ESCs were determined by 2695-996 Waters Alliance HPLC and Finnigan TSQ mass spectrometer to control the quality of ESCs (By Xiao HB, Dalian Institute of Chemical Physics, Chinese Academy of Sciences). The primary plant of Stellera chamaejasme $L$ was identified by He XR at Institute of Chinese Materia Medica, China Academy of Chinese Medical Sciences where all testing samples were deposited.

\section{Materials and reagents}

RPMI-1640 medium, fetal bovine serum (FBS), penicillinstreptomycin and trypsin- ethylenediaminetetraacetic acid (EDTA)were purchased from Gibco (Grand Island, NY, USA). 3-(4,5-Dimethylthiazol-2-yl)-2,5-diphenyltetrazolium bromide (MTT), dimethyl sulfoxide (DMSO) and protamine were provided by Sigma Chemical Co. (St. Louis, MO, USA). 5-fluorouracil (5-FU) injection was from Shang Hai Xu Dong Hai Pu Pharmaceutical Co. Ltd, Shanghai, China. Acutase was purchased from EBioScience (San Diego, CA, USA). Caspase-3,-8 colorimetric protease assay kits were purchased from Chemicon International, Inc. (Temecula, CA, USA). Fas, Fas-L, tumor necrosis factor receptor-1 (TNF-R1) ELISA kits were from R\&D Systems (Minneapolis, MN, USA). Tumor necrosis factor- $\alpha$ (TNF- $\alpha$ ) radioimmunoassay kit was from the radioimmunoassay institute of General Hospital of PLA, China. The biocompatible modified polyvinylidene difluoride (mPVDF) hollow fibers (CellMaxs Implant Membranes) with a Mr $500 \mathrm{kDa}$ cutoff and $1.0 \mathrm{~mm}$ inner diameter were purchased from Spectrum Laboratories Inc. (Breda, The Netherlands). All the other chemicals used, unless otherwise stated, were obtained from Sigma Chemicals.

\section{Animals and animal ethical statement}

Six to eight weeks old male $\mathrm{Nu} / \mathrm{Nu}$ Nude Mice (from Beijing Vital River Laboratory Animal Technology Co. Ltd) were raised and maintained under specific pathogen free (SPF) sterile condition. All studies involving animals were conducted according to the welfare and ethical guidelines for experimental animal drafted by Beijing Experimental Animal Management Office (Executed on January 1, 2006) and approved by Committee for Control and Supervision of Experiments on Animals of Institute of Chinese Materia Medica, China Academy of Chinese Medical Sciences.

\section{Cell culture}

Two non-small-cell lung carcinoma cell lines of NCIH157, NCI-H460 were purchased from the Cell Culture Center of the Chinese Academy of Medical Science. Two liver cancer cell lines of BEL-7402, SK-HEP-1 were obtained from Cell Bank, Shanghai Institutes for Biological Sciences, Chinese Academy of Sciences. Cells were grown in 1640 medium containing 10\% (v/v) FBS and incubated at $37^{\circ} \mathrm{C}$ in a $5 \% \mathrm{CO}_{2}$ humidified atmosphere.

\section{Preparation and in vivo implantation of the hollow fibers}

The hollow fiber tumor models were made by referring to the method of Hollingshead MG [1]. Hollow fibers were flushed with $70 \%$ ethanol solution followed by distilled water for hydration, then autoclaved $\left(121^{\circ} \mathrm{C}\right.$ for 
$40 \mathrm{~min})$ to sterilize. The sterilized fibers were stored in the tray at $4^{\circ} \mathrm{C}$ to wait for to be used. Cells were cultured in accordance with the method described above. Cell density was controlled at 70-90\% confluence at the day of the implantation. Cells were digested conventionally, adjusting the cell concentration in the range of $1 \times 10^{6}-10 \times 10^{6} / \mathrm{ml}$. Cell counts and activity identification were used trypan blue exclusion method. Adding an appropriate amount of 1640 medium containing 20\% FBS to adjust the cells to a desired concentration, hollow fibers were removed from the tray and placed on the work surface flushed with cold fresh medium. Cells were injected into the fibers with a syringe (18 gauge needle) and fibers were sealed every $2 \mathrm{~cm}$ with heat-sealer for 3-5 seconds. Fibers were cut off in the middle of the heat seal segments. Fibers were put into 6-well plates preloaded with medium to culture overnight. Every nude mouse was anesthetized with sodium pentobarbital and the abdomen was incised, inserting the hollow fibers into abdominal cavity. After abdominal incision was sutured, a small incision was made in the back neck and hollow fibers were placed subcutaneously through the transplant casing.

\section{Cytotoxic assessment of ESCs}

45 male nude mice (body weight range was 18-20 g) were made into hollow fiber tumor models according to the method above. Every mouse was loaded with 4 tumor cells: NCI-H157, NCI-H460, BEL-7402 and SK-HEP-1. These mice were divided into nine groups according to the weight: control (saline), solvent (10\%DMSO), $20 \mathrm{mg} /$ $\mathrm{kg} 5-\mathrm{Fu}, 4.5 \mathrm{mg} / \mathrm{kg}$ ESC, $3.0 \mathrm{mg} / \mathrm{kg}$ ESC, $25 \mathrm{mg} / \mathrm{kg}$ ESC- 1 , $16.75 \mathrm{mg} / \mathrm{kg}$ ESC-1, $1.5 \mathrm{mg} / \mathrm{kg}$ ESC-2, $1.0 \mathrm{mg} / \mathrm{kg}$ ESC-2. The mice were treated on 4 day by intraperitoneal administration with ESCs (The doses of ESCs were based on the results of their maximum tolerated dose (MTD) experiments, the high dose $=[\mathrm{MTD} \times 1.5] / 4$ and the low dose $=$ $0.67 \times$ the high dose [2]). The mice were sacrificed at day 8 and the fibers were retrieved from the mice. Excess host tissue was removed and the fibers were transferred into prewarmed medium and incubated for at least $1 \mathrm{~h}$ to be waited for pharmacodynamic analysis. The MTT assay was used to determine cytotoxicity of the cancer cells to the ESCs after isolation of the fibers. The fibers were placed into $2 \mathrm{ml}$ of fresh, prewarmed 1640 medium in sixwell plates and allowed to equilibrate for $30 \mathrm{~min}$ at $37^{\circ} \mathrm{C}$. Prewarmed 1640 medium $(1.5 \mathrm{ml})$ containing $1 \mathrm{mg} \mathrm{MTT/}$ $\mathrm{ml}$ was added to each well. After a $4 \mathrm{~h}$ incubation at $37^{\circ} \mathrm{C}$ in a $5 \% \mathrm{CO}_{2}$ humidified atmosphere, the culture medium was aspirated and $2 \mathrm{ml}$ normal saline containing $2.5 \%$ protamine sulphate was added into each well. The fibers were stored at $4^{\circ} \mathrm{C}$ for $24 \mathrm{~h}$. Each fiber was transferred to 24well plates after being removed debris outside of the fibers. The fibers were cut into half and dried at room temperature (RT). $250 \mu \mathrm{l}$ DMSO was added into each well to dissolve formazan crystals for $4 \mathrm{~h}$ at $\mathrm{RT}$ on a rotating platform while protected from the light. Aliquots of $150 \mu \mathrm{l}$ of extracted solution were transferred to individual wells in 96-well plates and absorbance value was measured at $490 \mathrm{~nm}$ using a spectrophotometer (ELX800 type, BIOTEX Instruments, INC, Winooski, VT, USA). The inhibition rate (IR) was calculated as follows.

$$
\text { Inhibition } \operatorname{rate}(\%)=1-\frac{\mathrm{OD}_{\text {treatment }}-\mathrm{OD}_{\text {pre-implantation }}}{\mathrm{OD}_{\text {solvent }}-\mathrm{OD}_{\text {pre-implantation }}}
$$

\section{Determination of apoptotic effects induced by ESCs}

36 male nude mice (body weight range was 18-20 g), according to the above method, were charged hollow fibers with NCI-H460 lung cancer cells intraperitoneally and subcutaneously. Mice were divided into control, $20 \mathrm{mg} /$ $\mathrm{kg} \mathrm{5-Fu,} 4.5 \mathrm{mg} / \mathrm{kg} \mathrm{ESC}, 3.0 \mathrm{mg} / \mathrm{kg} \mathrm{ESC}, 1.5 \mathrm{mg} / \mathrm{kg}$ ESC-2, $1.0 \mathrm{mg} / \mathrm{kg}$ ESC-2. The administration method was same as that mentioned above. On the collection day, the fibers were removed from sacrificed mice and transferred to 6-well plates added with $2 \mathrm{ml}$ preheating acutase to digest for $30 \mathrm{~min}$. Then the cells were flush out from fibers to be wait for detection of indexes related to apoptosis.

\section{Measurement of apoptotic rate}

The cancer cells were retrieved from the fibers and prepared for flow cytometric analysis to measure apoptotic rate. Briefly, the cells were washed with phosphate balanced solution (PBS) and fixed with $70 \%$ ethanol for $30 \mathrm{~min}$ on ice. After centrifugation, the pellet was resuspended in $400 \mathrm{ml}$ hypotonic propidium iodide (PI) solution (containing $0.5 \mathrm{mg} / \mathrm{ml}$ Ribonuclease, $50 \mathrm{mg} / \mathrm{ml} \mathrm{PI}$, $1 \mathrm{mg} / \mathrm{ml}$ sodium citrate, $1 \mathrm{ml} / \mathrm{ml}$ Triton $\mathrm{X}-100$ in saline) and incubated on ice in the dark for at least $15 \mathrm{~min}$. Then the cells were analysized by flow cytometer (BectonDickinson, USA).

\section{Detection of caspase activities}

Caspase 3, 8, 9 activities were measured with caspase assay kits. $1 \times 10^{6}$ cells were collected from fibers and lysised with lysate on ice for $10 \mathrm{~min}$ and centrifuged at $20,000 \mathrm{~g}$ for $15 \mathrm{~min}$. The supernatant was transferred to a pre-cooled centrifuge tube and determined the activities of caspases immediately. Reaction system was set according to kits and incubated at $37^{\circ} \mathrm{C}$ for $120 \mathrm{~min}$. Absorbance value was measured at $405 \mathrm{~nm}$ when the reaction system color obviously changed. If the color did not change significantly, incubation time of reaction system may be extended, even overnight incubation. Deference of A405 absorbance between treatment and the control was p-nitroaniline (pNA) absorbance of sample catalyzed by caspases. Catalytic amount of pNA of can be calculated 
through the pNA standard curve. Enzyme activity unit was defined as the amount of caspase enzyme catalyzing $1 \mathrm{nmol}$ pNA substrate when the substrate was saturation. Each sample protein concentration was determined by Bradford method to calculate the enzyme activity in unit weight of protein of sample.

\section{Expression of Fas, Fas-L, TNF-R1 with Elisa assay}

Cells removed from fibers were collected after conventional digestion and cleavage. The standard was diluted according to the Elisa kit. $100 \mu \mathrm{l}$ standard or each test sample was added into wells of reaction plates and incubated for $120 \mathrm{~min}$ at $37^{\circ} \mathrm{C}$. Plates were washed with washing liquid 5 times, and then first antibody working solution of $100 \mu \mathrm{l}$ was added and incubated for $60 \mathrm{~min}$ at $37^{\circ} \mathrm{C}$. Plates were washed another time. $100 \mu \mathrm{l}$ Horseradish Peroxidase (HRP) working solution was added and incubated for $30 \mathrm{~min}$. Plates were washed again. $100 \mu \mathrm{l}$ substrate working solution was added and reacted in the dark for $15 \mathrm{~min}$ at $37^{\circ} \mathrm{C}$, and then $100 \mu \mathrm{l}$ of Stop Solution was added. Absorbances of samples were measured at $450 \mathrm{~nm}$ in microplate reader within $30 \mathrm{~min}$.

\section{Expression of TNF-a with radioimmunoassay}

Cells flushed from the hollow fibers were washed with PBS, and then cells were lysised with ultrasonic cell crasher. Using liquid competitive inhibition principle, the cell samples were determined with balance method. The samples or standard and limited antisera or antigen together generated competitive binding reaction. After the reaction, added immune separating agent to isolating the antigen-antibody complex, radioactivity of compound was determined and the standard combination rate was calculated. Make the standard curve and determine the sample concentration.

\section{Statistical analysis}

All results were expressed as mean $\pm \mathrm{SD}$. One way analysis of variance (ANOVA) with multiple comparison tests was used. $\mathrm{P}<0.05$ was considered as significant. Statistical tests were performed using SPSS version 12.0.

\section{Results}

\section{Comparisons of anti-tumor activities of ESCs based on HFA}

For the NCI-157 cells: In the SC (subcutaneous) fibers, the IRs of 4.5,3.0 mg/ $\mathrm{kg}$ ESC and $1.5 \mathrm{mg} / \mathrm{kg}$ ESC-2 were $43.05 \%, 77.15 \%$ and $43.13 \%$ respectively; In the IP (intraperitoneal) fibers, the IRs of $4.5 \mathrm{mg} / \mathrm{kg}$ ESC and $1.0 \mathrm{mg} /$ kg ESC-2 were $96.33 \%$ and $49.78 \%$ respectively. For the NCI-H460 cells: In the SC fibers, the IRs of $4.5,3.0 \mathrm{mg} /$ $\mathrm{kg}$ ESC, $1.5,1.0 \mathrm{mg} / \mathrm{kg}$ ESC-2 and $16.75 \mathrm{mg} / \mathrm{kg}$ ESC-1 were $98.62 \%, 60.01 \%, 79.71 \%, 100.84 \%$ and $45.54 \%$ respectively; In the IP fibers, the IRs of $4.5 \mathrm{mg} / \mathrm{kg}$ ESC and $1.5,1.0 \mathrm{mg} / \mathrm{kg}$ ESC-2 were $48.70 \%$ and $68.71 \%, 108.34 \%$ respectively. For the Bel-7402 cells, In the SC fibers, the IRs of $1.0 \mathrm{mg} / \mathrm{kg}$ ESC- 2 and $25 \mathrm{mg} / \mathrm{kg}$ ESC- 1 were $43.91 \%$ and $55.03 \%$ respectively; In the IP fibers, the IR of $4.5 \mathrm{mg} / \mathrm{kg}$ ESC was $43.38 \%$. For the SK-HEP-1 cells: In the SC fibers, the IR of $4.5 \mathrm{mg} / \mathrm{kg}$ ESC was $40.24 \%$; In the IP fibers, the IRs of $4.5,3.0 \mathrm{mg} / \mathrm{kg}$ ESC, $1.5,1.0 \mathrm{mg} /$ $\mathrm{kg}$ ESC-2 were $46.78 \%, 52 \%$ and $44.42 \%, 47.33 \%$. The results showed that ESC and ESC-2 have obvious toxicity to 4 tumor cells in hollow fibers loaded in nude mice (see Figure 1).

\section{Apoptosis induced by ESCs in $\mathrm{NCl}-\mathrm{H} 460$ cells from the implanted hollow fibers}

Retrieval of the cells from the implanted fibers enabled to evaluate apoptosis induction. The cells retrieved from the fibers in control animals contained on average 7.40 \pm 2.78 apoptotic cells. Otherwise, the cells retrieved from the fibers in $4.5,3.0 \mathrm{mg} / \mathrm{kg}$ ESC and $1.5,1.0 \mathrm{mg} / \mathrm{kg}$ ESC-2 treatment groups contained on average 20.86 \pm 2.39 , $19.09 \pm 3.60,23.35 \pm 4.45,18.76 \pm 6.58$ apoptotic cells respectively, about 2.54 to 3.16 fold increase to that of control group (see Figure 2).

Influence of ESCs on caspase 3, 8, 9 activities in $\mathrm{NCl}-\mathrm{H} 460$ cells from the implanted hollow fibers

4.5, $3.0 \mathrm{mg} / \mathrm{kg}$ ESC and $1.5 \mathrm{mg} / \mathrm{kgESC}-2$ can significantly improve caspase 3 enzyme activity of NCI-H460 cells and increase $1.76,1.47$ and 1.41 folds $(41.17 \pm 6.74,34.49 \pm$ $2.40,32.80 \pm 1.59)$ respectively compared to that of control group (23.32 \pm 2.26$) ; 4.5 \mathrm{mg} / \mathrm{kg}$ ESC and $1.5 \mathrm{mg} / \mathrm{kg}$ ESC-2 can also significantly improve caspase 8 enzyme activity of NCI-H460 cells and increase 1.49 and 1.47 folds $(19.98 \pm 4.19,19.69 \pm 2.54$,$) compared to that of control$ group (13.40 \pm 4.17$)$; but ESCs did not increase the caspase 9 enzyme activity of NCI-H460 cells (see Figure 3 ).

\section{Influence of ESCs on expression of Fas and Fas- $L$ in $\mathrm{NCl}-\mathrm{H} 460$ cells from the implanted hollow fibers} Compared with the control group, Fas and Fas-L expression of NCI-H460 cells in all ESCs groups has no significant increase (see Figure 4).

\section{Influence of ESCs on expression of TNF- $a$ and TNFR1 in $\mathrm{NCl}-\mathrm{H} 460$ cells from the implanted hollow fibers}

$3.0 \mathrm{mg} / \mathrm{kg} \operatorname{ESC}(1.29 \pm 0.03)$ significantly improved expression of TNF- $\alpha$ in NCI-H460 cells, whereas 1.5, $1.0 \mathrm{mg} / \mathrm{kg}$ ESC-2 $(0.24 \pm 0.09,0.33 \pm 0.13)$ decreased significantly in NCI-H460 cell compared with the control group $(0.78 \pm 0.36) ; 1.0 \mathrm{mg} / \mathrm{kg}$ ESC-2 (39.10 \pm 10.15$)$ increased significantly TNFR1 expression in NCI-H460 cell compared with the control group $(20.07 \pm 3.02)$ (see Figure 5). 


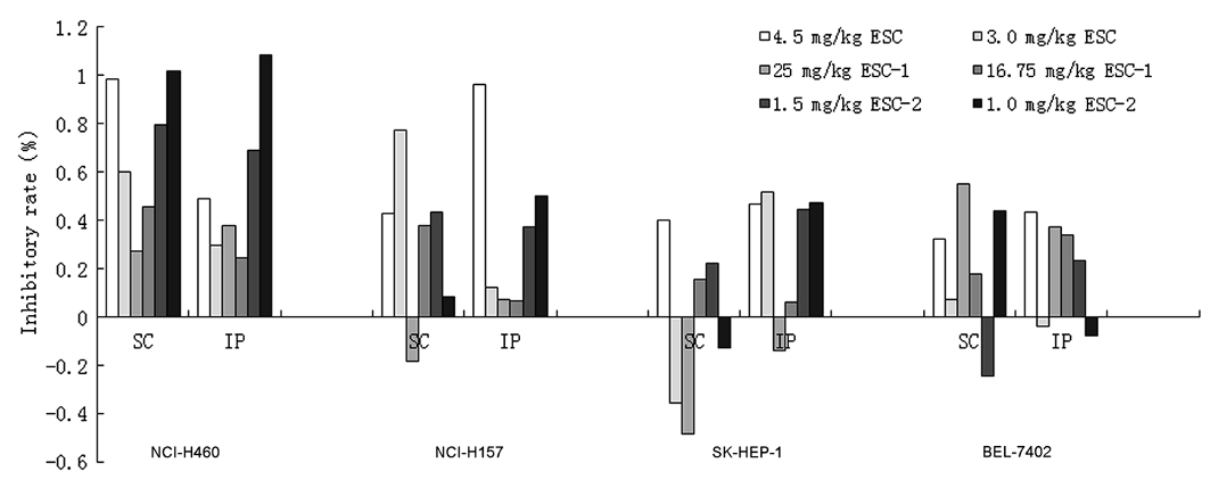

Figure 1 Antitumor activities of ESCs on 4 tumor cell lines (NCI-H460, NCI-H157, SK-HEP-1 and BEL-7402) based on hollow fiber assay. SC: subcutaneous fibers, IP: intraperitoneal fibers.

\section{Discussion and conclusions}

In this study, we used hollow fiber assay (bearing NCIH157, NCI-H460, BEL-7402, SK-HEP-1 4 tumor cell lines, subcutaneously and intraperitoneally implanted sites for each cell line for every animal)to evaluate the anti-tumor pharmacological effects of Stellera chamaejasme $L$ Extracts in vivo and traced the main fragments of Stellera chamaejasme L. Of all the ESCs treatment mice, the average body weight losses were all $<20 \%$ with no drug-related deaths, suggesting that all the experiment mice could tolerate ESCs during the experimental process.

It was considered positive that in vivo inhibition rate was more than $40 \%$ according to evaluation standard of in vivo antitumor nature product crude extract [16]. The hollow fiber assay results showed that ESC, ESC-2 had obvious in vivo cytotoxic effect and both produced $>40 \%$ growth inhibition on four tumor cell lines, ESC-1 only one dose had certain inhibition on NCI-H460 and BEL7402 cells. Especially, the cell killing effect (a reduction in cell mass below the input mass and inhibition rate

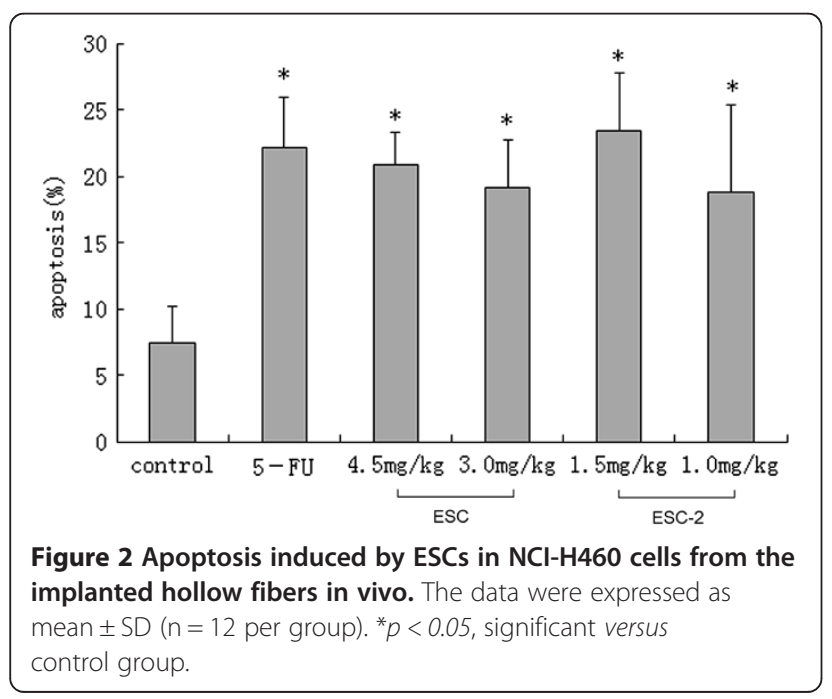

was more than $100 \%$ ) was observed in NCI-H460 cell line in mice of ESC-2 group. Therefore, the order of antitumor effects of ESCs was comprehensively evaluated according to the effect strength (ESC-2 had cell killing effect), effect dose (administration dose of ESC-2 was 1/

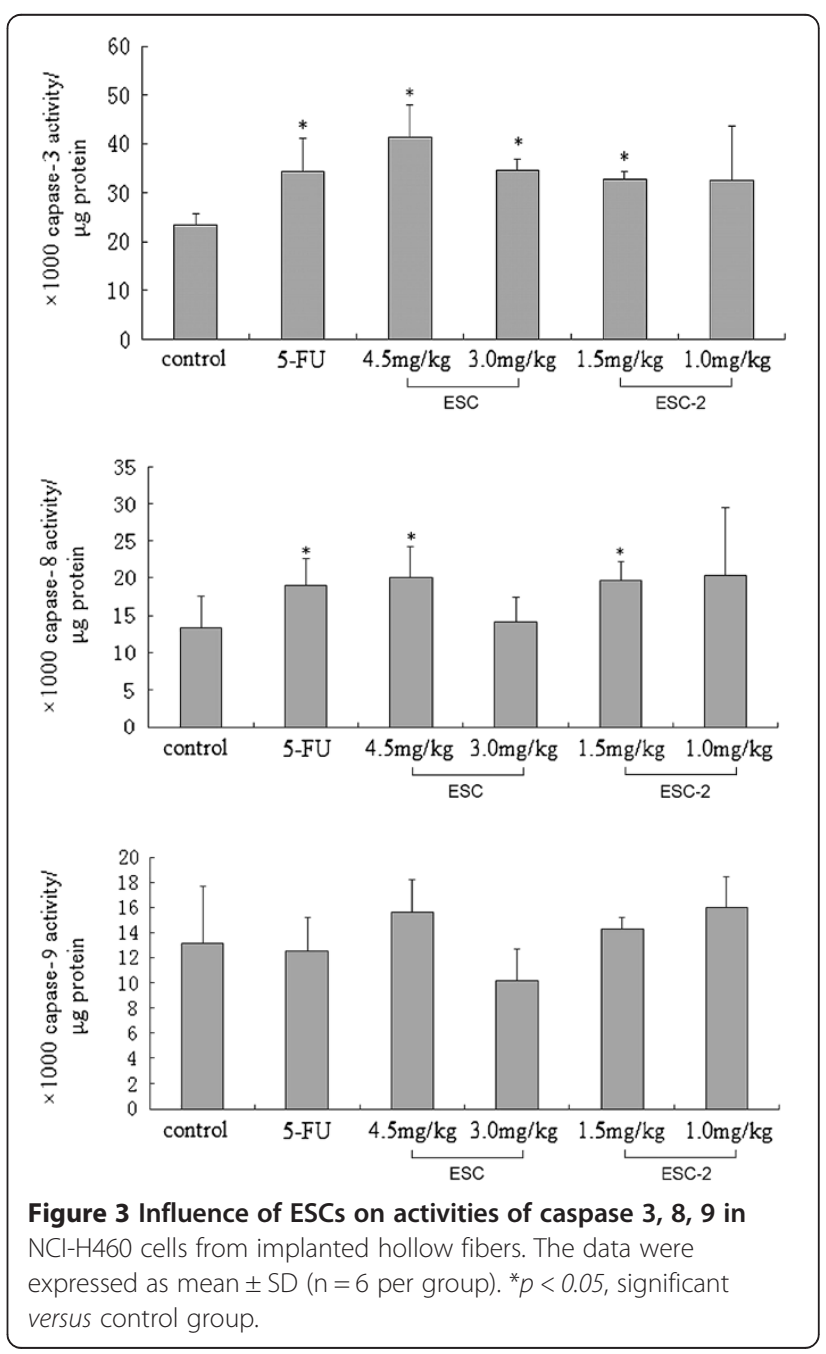




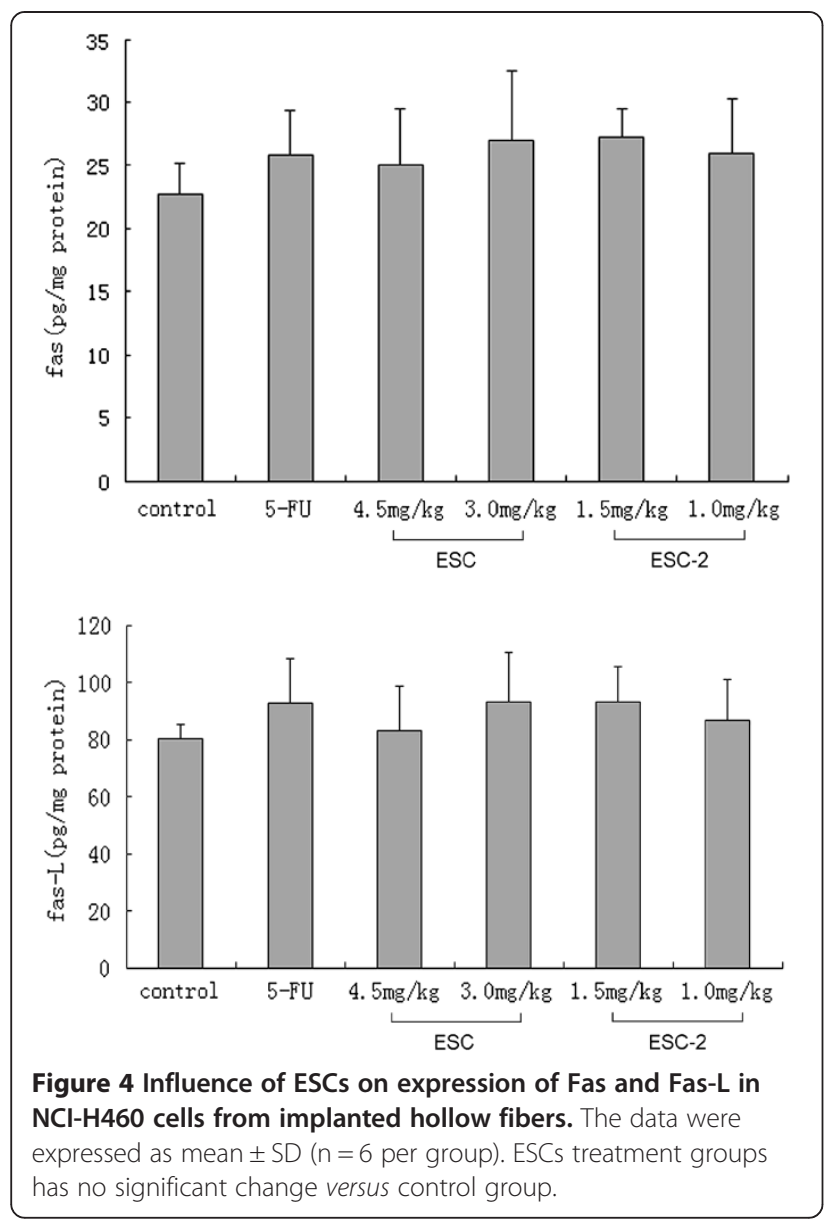

3 of ESC) and the antitumor spectrum (ESC-2 had obvious inhibitory effects on 4 cell tumor lines): ESC-2 > $\mathrm{ESC}>\mathrm{ESC}-1$.

Comparison of sensitivity of ESCs to tumor cells, NCIH460 cell line was the most because that all ESCs had inhibition on it. ESC-2 showed the strongest inhibition and inhibition rates of two sites (SC and IP) of NCIH460 cells were more than $100 \%$. Follow the ESC-2 was ESC and inhibition rate of two sites (SC and IP) were nearly $100 \%$. Furthermore, ESC-1 showed certain inhibition in SC site on NCI-H460 cells.

In our previous in vitro experiment, we found that ESCs could induce the tumor cells apoptosis by activating death receptor pathway. Therefore we selected the most sensitive NCI-H460 cell line to further confirm the apoptotic effect of ESCs in vivo based on HFA. The flow cytometry results showed that $4.5 \mathrm{mg} / \mathrm{kg} \mathrm{ESC}$, and $1.5 \mathrm{mg} / \mathrm{kg}$ ESC-2 increased significantly apoptosis rates in NCI-H460 cells in vivo. Enzymatic activity assay also confirmed the ESC and ESC-2 could significantly increase the activities of caspase 3 and caspase 8 in NCIH460 cells. These results suggested that ESC and ESC-2 induce tumor cell apoptosis through activation signal of
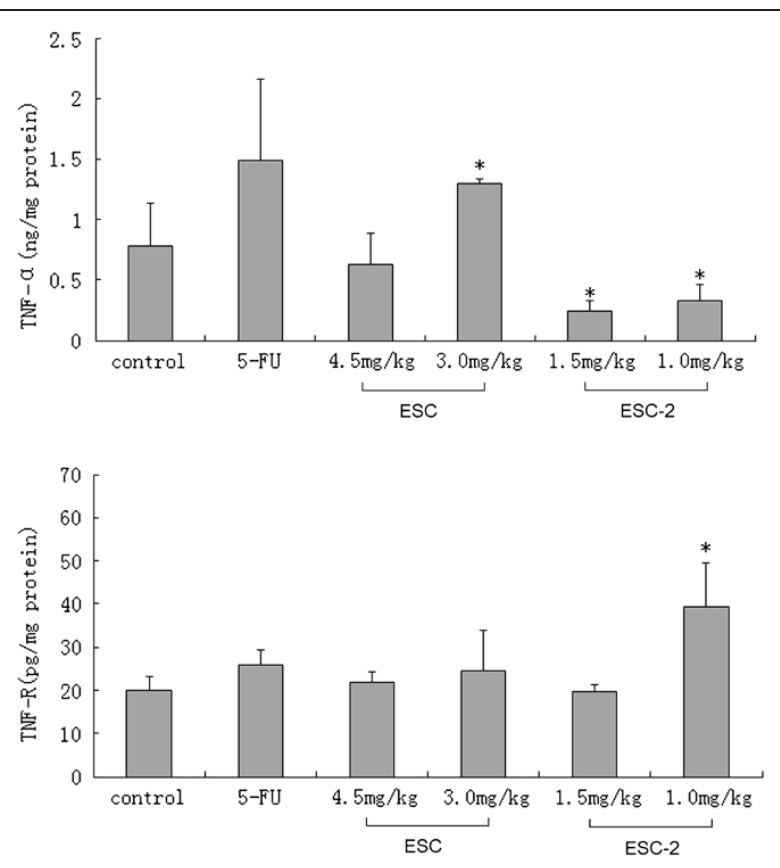

Figure 5 Influence of ESCs on expression of TNF- $a$ and TNFR1 in $\mathrm{NCl}-\mathrm{H} 460$ cells from implanted hollow fibers. The data were expressed as mean \pm SD ( $n=6$ per group). ${ }^{*} p<0.05$, significant versus control group.

the death receptor pathway in vivo which was consistent with the in vitro results $[14,15]$.

The death receptor families contained Fas, TNFR1, death receptor (DR3, DR5), TNF related apoptosis inducing ligand receptor (TRAIL-R1, TRAIL-R2), etc. [17]. Which pathway would the ESCs acted on?

We tested the classic death receptors, Fas, TNFR1 and their ligands Fas-L, TNF- $\alpha$. The Fas/Fas-L system was a key regulator of apoptosis. The results showed that ESC, ESC-2 had no significant effects on Fas/Fas-L pathway which was not consistent with the in vitro results. Maybe after the metabolism in vivo, the targets of ESCs changed. TNFR1/ TNF- $\alpha$ signal system was another important death receptor pathway which was not observed in our in vitro experiment. TNF- $\alpha$ was a multifunctional cytokine, mainly involving in inflammation and immune responses. It had a direct cytotoxic effect on tumor cells and could cause tumor necrosis. Recent researches had demonstrated that TNF- $\alpha$ inhibited certain tumor cell proliferation and induced apoptosis of tumor cells [18]. But few study focused on the role of endogenous tumor TNF- $\alpha$, some scholars believed that the endogenous TNF- $\alpha$ could promote tumor cells to produce oxygen free radical ions, causing DNA damage or fracture $[19,20]$ and was conducive to the treatment of tumors. Downregulation of endogenous TNF- $\alpha$ to increase sensitivity of exogenous TNF- $\alpha$ (produced by other cells) on tumor cells was believed to be another reason of TNF- $\alpha$ killing 
tumor cells [21]. Other reports showed that TNF- $\alpha$ produced by tumor cells would injury normal tissue, promote tumor metastasis and related to many paraneoplastic syndrome (such as hypercalcemia, lipemia and tumor associated cachexia) [22,23]. Visibly, endogenous TNF- $\alpha$ is a double-edged sword. In this experiment, we observed that regulation roles of ESC, ESC-2 on endogenous TNF$\alpha$ expression of tumor cells were opposite: $3.0 \mathrm{mg} / \mathrm{kg}$ ESC significantly upregulated whereas $1.5,1.0 \mathrm{mg} / \mathrm{kg}$ ESC-2 downregulated the expression of TNF- $\alpha$. ESC might upregulate the level of TNF- $\alpha$ to direct its effect of killing tumor and ESC-2 may downregulate endogenous TNF- $\alpha$ to enhance sensitivity of exogenous TNF- $\alpha$ to tumor cells. The possible and reasonable explanation for the results was that because ESC-2 was isolated from ESC, the target ingredients to TNF- $\alpha$ of ESC-2 may be changed.

TNFR1, another death receptor protein, combining with TNF- $\alpha$ might induce typtical apoptosis of caspase dependent pathway. On the other hand, this combination might activate the nuclear factor kappa-lightchain-enhancer of activated B cells (NF-kB) and c-Jun-N terminal kinase (JNK) signal pathway by recruitment of TNF receptor-associated factor (TRAF2) and Receptor interacting protein (RIP) [24-26]. $1.0 \mathrm{mg} / \mathrm{kg}$ ESC-2 obviously increased TNFR1 expression which suggested that ESC-2 inducing apoptosis of NCI-H460 cells might be related to upregulation of TNFR1 receptor.

The results above showed ESC-2 had the similar antitumor effect to that of ESC in vivo and further confirmed that ESC-2 may be the main antitumor active fraction of ESC, which was consistent with the in vitro result.

\section{Competing interests}

The authors declare that they have no competing interests.

\section{Authors' contributions}

$X L$ was the main experimental investigator and had drafted the manuscript QY, GZ and YL helped to establish the hollow fiber tumor model. YC and XW helped to complete the experiments of caspases acticities and elisa assay. YW helped to correct the language of the manuscript. YW helped to analysis the data. XZ supervised the study and the manuscript. All authors read and approved the final manuscript.

\section{Acknowledgments}

This work was supported by the China Postdoctoral Science Foundation (No. 20090450550); Optional Research Project sponsored by China Academy of Chinese Medical Science (No.Z02065); National Major Scientific and Technological Special Project for "Significant New Drugs Development" during the Twelfth Five-year Plan Period (No.2013ZX09301307001004); Foundation of Beijing Institute of Hepatology (No. BJIH-01210).

\section{Author details}

'Beijing Institute of Hepatology and Beijing YouAn Hospital, Capital Medical University, Beijing 100069, China. 'Institute of Chinese Materia Medica, China Academy of Chinese Medical Sciences, No 16 Nan Xiao Jie, Dong Zhi Men Nei, Dong Cheng Qu, Beijing 100700, China.

Received: 5 April 2013 Accepted: 27 March 2014

Published: 31 March 2014

\section{References}

1. Hollingshead MG, Alley MC, Camalier RF, Abbott BJ, Mayo JG, Malspeis L, Grever MR: In vivo cultivation of tumor cells in hollow fibers. Life Sci 1995, 52:131-141.

2. Melinda G, Hollingshead MG, Carter JP, Dougherty K, Bonomi CA: The Hollow Fiber Assay In Cancer Efficacy Testing In The Developmental Therapeutics Program At The National Cancer Institute. AACR Education Book; 2005:351-354

3. Liu X, Yang Q, Li Y, Pan G, Han X, Weng X, Zhang Y, Wang Y, Zhu X: Application of hollow fiber assay in anti-Cancer drug research. Acta Laboratorium Animalis Scientia 2009, 17:392-396.

4. Mi Q, Cui B, Silva GL, Lantvit D, Lim E, Chai H, Hollingshead MG, Mayo JG, Kinghorn AD, Pezzuto JM: Pervilleines $B$ and $C$, new tropane alkaloid aromatic esters that reverse the multidrug-resistance in the hollow fiber assay. Cancer Lett 2002, 184:13-20.

5. Hassan S, Dhar S: Cytotoxic activity of a new paclitaxel formulation, Pacliex, in vitro and in vivo. Cancer Chemother Pharmacol 2005, 55:47-54

6. Suggitt M, Cooper PA, Shnyder SD, Bibby MC: The hollow fibre model facilitating anti-cancer preclinical pharmacodynamics and improving animal welfare. Int J Oncol 2006, 291:493-1499.

7. Kiakos K, Sato A, Asao T, McHugh PJ, Lee M, Hartley JA: DNA sequence selective adenine alkylation, mechanism of adduct repair, and in vivo antitumor activity of the novel achiral seco-amino-cyclopropylbenz [e] indolone analogue of duocarmycin AS-1-145. Mol Cancer Ther 2007, 6:2708-2718.

8. Li XL, Liu JY, Lu R, Xu Q, Zhu ZF, Wang L, Zhou CL, Jia J, Fu Z, Yao Z: Evaluation of the therapeutic efficacy of tripeptide tyroserleutide (YSL) for human hepatocarcinoma by in vivo hollow fiber assay. Invest New Drugs 2008, 26:525-529.

9. Temmink OH, Prins HJ, van Gelderop E, Peters GJ: The hollow fibre assay as a model for in vivo pharmacodynamics of fluoropyrimidines in colon cancer cells. Br J Cancer 2007, 2007:96.

10. Hall LA, Krauthauser CM, Wexler RS, Hollingshead MG, Slee AM, Kerr JS: The hollow fiber assay:continued characterization with novel approaches. Anticancer Res 2000, 20:903-911.

11. Krauthauser CM, Hall LA, Wexler RS, Slee AM, Mitra J, Enders GH, Kerr JS: Regulation of gene expression and cell growth in vivo by tetracycline using the hollow fiber assay. Anticancer Res 2001, 21:869-872.

12. Zhang GJ, Chen TB, Hargreaves R, Sur C, Williams DL Jr: Bioluminescence imaging of hollow fibers in living animals: its application in monitoring molecular pathways. Nat Protoc 2008, 3:891-899.

13. Liu X, Li Y, Yang Q, Liu A, Zhu X: Anti-tumor effect of alcohol extract of Stellera chamaejasme in vitro. Zhongguo Zhong Yao Za Zhi 2010, 35:3048-3051.

14. Liu X, Li Y, Yang $Q$, Chen Y, Weng X, Wang Y, Li N, Zhu X: In vitro inhibitory and pro-apoptotic effect of stellera chamaejasme $L$ extract on human lung cancer cell line NCI-H157. J Tradit Chin Med 2012, 32:404-410.

15. Liu X, Zhu X: Stellera chamaejasme L. extract induces apoptosis of human lung cancer cells via activation of the death receptor-dependent pathway. Exp Ther Med 2012, 4:605-610.

16. Situ Z, Wu J: Cells Culture. Xi'an world publishing corporation; 1996:135

17. Thorburn A: Death receptor-induced cell killing. Cell Signal 2004, 16:139-144.

18. Rübe CE, van Valen F, Wilfert F, Palm J, Schuck A, Willich N, Winkelmann W, Jürgens $H$, Rübe C: Ewing's sarcoma and peripheral primitive neuroectodermal tumor cells produce large quantities of bioactive tumor necrosis factor-alpha (TNF-alpha) after radiation exposure. Int $\mathrm{J}$ Radiat Oncol Biol Phys 2003, 56:1414-1425.

19. Fedorocko P, Egyed A, Vacek A: Irradiation induces increasedproduction of haemopoietic and proinflammatory cytokines in the mouse lung. Int $J$ Radiat Biol 2002, 78:305-313.

20. Gupta VK, Park JO, Jaskowiak NT, Mauceri HJ, Seetharam S, Weichselbaum $\mathrm{RR}$, Posner MC: Combined gene therapy and ionizing radiation is a novel approach to treat human esophageal adenocarcinoma. Ann Surg Oncol 2002, 9:500-504.

21. Rübe CE, Wifert F, Uthe D, Schmid KW, Knoop R, Willich N, Schuck A, Rübe C: Modulation of irradiation-induced tumor necrosis factor (TNF-a) expression in the lung tissue by pentoxifyline. Radiother Oncol 2002. 64:177-187.

22. Himeno T, Watanabe N, Yamauchi N, Maeda M, Tsuji Y, Okamoto T, Neda H, Niitsu Y: Expression of endogenous tumor necrosis factor as a protective protein against the cytotoxicity of exogenous tumor necrosis factor. Cancer Res 1990, 50:4941-4945. 
23. Rübe $C E$, van Valen F, Wifert F, Schuck A, Willich N, Winkelmann W, Jürgens $H$, Rübe C: Ewing's sarcoma and peripheral primitive neuro-ecto-dermal tumor cells produce large quantities of bioactive tumor necrosis factor-a (TNF-a) after radiation exposure. Int J Radiation Oncology Biol Phys 2003, 56:1414-1425.

24. Chosa N, Kyakumoto S, Kito N, Kamo M, Sato N: Mechanism of Fas-mediated cell death and its enhancement by TNF-alpha in human salivary gland adenocarcinoma cell line HSG. Eur J Oral Sci 2004, 112:338-346.

25. Chang L, Kamata H, Solinas G, Luo JL, Maeda S, Venuprasad K, Liu YC, Karin M: The E3 ubiquitin ligase itch couples JNK activation to TNF alpha-induced cell death by inducing c-FLIP(L) turn over. Cell 2006, 124:601-613.

26. Wang WH, Grégori G, Hullinger RL, Andrisani OM: Sustained activation of p38 mitogen-activated protein kinase and c-Jun $\mathrm{N}$-terminal kinase pathways by hepatitis $\mathrm{B}$ virus $\mathrm{X}$ protein mediates apoptosis via induction of Fas/FasL and tumor necrosis factor (TNF) receptor 1/TNF-alpha expression. Mol Cell Biol 2004, 24:10352-10365.

doi:10.1186/1472-6882-14-116

Cite this article as: Liu et al: Anti-tumor pharmacological evaluation of extracts from stellera chamaejasme $L$ based on hollow fiber assay. BMC Complementary and Alternative Medicine 2014 14:116.

\section{Submit your next manuscript to BioMed Central and take full advantage of:}

- Convenient online submission

- Thorough peer review

- No space constraints or color figure charges

- Immediate publication on acceptance

- Inclusion in PubMed, CAS, Scopus and Google Scholar

- Research which is freely available for redistribution 